\title{
'n Prakties Teologiese ondersoek na die betrokkenheid van gemeentes in die gemeenskap waarbinne hul bestaan
}

\author{
Author: \\ André Ungerer ${ }^{1,2}$ \\ Affiliations: \\ ${ }^{1}$ Reformed Theological \\ College, University of \\ Pretoria, South Africa \\ ${ }^{2}$ Department of Practica \\ Theology, University of \\ Pretoria, South Africa

\section{Note:} \\ This article has been based \\ on a doctoral dissertation \\ at the University of \\ Pretoria with the title: \\ 'Die verband tussen \\ gemeentebouprosesse \\ en missionale \\ gemeenteontwikkeling: 'n \\ Prakties Teologiese studie', \\ under the direction of Prof. \\ Dr Malan Nel as promotor. \\ The author gratefully \\ acknowledges Judy Coetsee \\ and Joyce Jordaan of the \\ Department Statistics \\ for their assistance and \\ guidance.
}

\section{Correspondence to:} André Ungerer

Email:

andreung@telkomsa.net

Postal address:

PO Box 6233, Flamwood

2572, South Africa

Dates:

Received: 08 June 2011

Accepted: 02 Aug. 2011

Published: 04 Nov. 2011

How to cite this article: Ungerer, A., 2011, " $n$ Prakties Teologiese ondersoek na die betrokkenheid van gemeentes in die gemeenskap waarbinne hul bestaan', HTS Teologiese Studies/Theological Studies 67(3), Art. \#1106, 9 pages. http://dx.doi.org/10.4102/ hts.v67i3.1106

(C) 2011. The Authors. Licensee: AOSIS OpenJournals. This work is licensed under the Creative Commons Attribution License.

\begin{abstract}
A Practical Theological research on the involvement of congregations in the community where they exist

The study deals with the question about the involvement of congregations of the two traditional Reformational churches in South Africa, namely the Dutch Reformed Church (DRC) and the Netherdutch Reformed Church of Africa (NRCA) in their communities. The question posed is whether the love of God is kept for the benefit of the congregation or whether it is also for the well-being of the community. The study comprises two parts, an introduction that deals with the theory of mission and service to the community. The second part is an empirical study where 12 projects were given as examples and congregations were asked about their involvement.
\end{abstract}

\section{Inleiding}

Die woorde God is liefde staan op vele kanselklede in talle kerkgeboue landwyd. Dit is bedoel om woorde van troos te wees, en tegelyk ook woorde wat 'n appél rig op die lewe van die gelowige teenoor sy of haar medemens. Van Rensburg (2009:35) vertel dat mense tydens die Sharpville- en Evaton-onluste in die 1960's probeer het om ' $n$ kerk in Sharpeville af te brand. Die swart evangelis en die wit predikant van die gemeente het geskok daar opgedaag en was verlig toe hulle sien hoe min skade aangerig was. Dit was net die kanselkleed met die woorde God is liefde daarop, en die litugiese ruimte wat uitgebrand het. Hulle het toe tussen die swart roet van die litugiese ruimte gekniel en die swart evangelis het die volgende gebed gedoen:

O Here, ons dank $U$ dat $u$ liefde nie op lappe staan nie, maar aan ' $n$ kruis gehang het. Hulle kan maar al die lappe verbrand, dan sal ons nog weet: God is liefde.

(Van Rensburg 2009:35)

Hierdie gebeure laat die vraag ontstaan of die betekenis van God is liefde op baie kanselklede nie maar net woorde op lappe is, wat in kerkgeboue agtergelaat word terwyl 'n wêreld daarbuite honger na God se liefde nie. Die gemeente buite die vier mure van die kerkgebou behoort by uitstek draers en uitdelers van God se liefde te wees. Met hierdie studie word daar gepoog om God is liefde deur middel van barmhartigheidsdiens aan veral mense (nie-lidmate) buite die gemeente, te beskryf en te bevorder.

\section{Teologiese begronding}

Die missio Dei is die goeie nuus dat God die wêreld lief het en dat Hy betrokke is in die wêreld. God is ' $n$ God vir mense en die missio Dei is God se aktiwiteit wat beide die kerk en wêreld omarm en waaraan die kerk die voorreg het om deel te neem (Bosch 1991:10, 391; Hancke 2005:25). Nog sterker gestel, die missio Dei is die Drie-enige God wat die kerk die wêreld instuur (Bosch 1979:242, 1991:390). Om deel te neem aan sending, is om deel te neem aan die beweging van God se liefde aan mense omdat God ' $n$ fontein van sendende liefde is:

Mission has its origin in the heart of God. God is a fountain of sending love. This is the deepest source of mission. It is impossible to penetrate deeper still; there is a mission because God loves people.

(Bosch 1991:392)

Bosch (1991:393-510) beskryf in diepte wat sending alles behels. Sending is bemiddeling van redding, 'n soeke na geregtigheid, evangelisasie, kontekstualisering, bevryding, inkulturasie, algemene getuienislewering, 'n bedieningsopdrag vir al God se kinders, getuienis teenoor ander gelowe, sending as teologie en sending as aksie in hoop. Uit die genoemde lys blyk dit duidelik dat dit in sending oor meer gaan as die klassieke benadering van zieltjes winnen, soos Heitink (2007:192; kyk ook Schutte 2003:254) dit stel. Volgens Armstrong (1979:60) is 'Christianity is a religion about a person, from persons ... but it is more. It is for persons'. Hy meen dat sosiale aksie 'n natuurlike gevolg van diensevangelisasie (service evangelism) is, maar nie andersom nie. 'But it is not possible, in my opinion, to be meaningful involved in service evangelism without being involved in social action' (Armstrong 1979:58). Hoewel die klassieke benadering onontbeerlik is 
vir die Christelike verstaan van redding, lê die gevaar daarin dat dit die verstaan van redding geweldig vereng as bloot 'n ontsnapping weg van God se toorn en die verlossing van die indiwidu se siel met die oog op die hiernamaals (Bosch 1991:398).

Bosch (1991) noem dat daar nog nooit in die geskiedenis soveel sosiale nood as in die 20ste eeu was nie. Maar nooit tevore was Christene in 'n beter posisie as vandag om iets aan hierdie nood te doen nie. Hy beskryf dan hierdie sosiale nood soos volg:

Poverty, misery, sickness, criminality, and social chaos have assumed unheard-of proportions. On unprecedented scale people have become thie victims of other people; homo homini lupus (The human being is a wolf to other human beings). Marginalized groups in many countries of the world lack every form of active and even passive participation in society; interhuman relationships are disintegrating; people are in the grip of a pattern of life from which they cannot possibly wrench themselves free; marginality characterizes every aspect of their existence.

(Bosch 1991:399-400)

Heitink (2007:181-182) skryf oor die moontlike aansluiting van die gemeente by die behoeftes van mense in haar omgewing en gee dadelik toe dat die woord behoefte 'lijdt nog altijd onder de verdenking van misbruik'. Tog noem hy vyf behoeftes waaraan 'n gemeente kan aandag gee:

- Daar is 'n groeiende behoefte by mense in hierdie anonieme samelewing om êrens te behoort. Daar is ' $n$ hunkering na gemeenskap waar mense mekaar ken en na mekaar se behoeftes omsien.

- Daar bestaan 'n behoefte aan singewing, eksistensiële belewenis, en spirituele lewensverdieping in antwoord op die oppervlakkigheid wat dikwels in die media aangebied word.

- 'n Behoefte aan inligting oor geloof, religie en morele kwessies.

- 'n Behoefte aan rituele tydens hoogtepunte en laagtepunte in die lewe, byvoorbeeld by die geboorte van 'n kind of die sterwe van 'n geliefde.

- Daar bestaan toenemende behoefte van uiteenlopende vorme van hulp, veral waar die staat nie vir almal na behore kan sorg nie. Die kerk is veral gerat om met pastoraat en diakonaat in hierdie behoefte te voorsien.

Volgens Dulles (2002:89) in sy hoofstuk oor die kerk as dienskneg, is die kerk die 'aktiewe subjek' en die wêreld die 'objek' met wie die kerk werk en wat die kerk probeer beïnvloed. Hy sluit by Bonhoeffer aan (1967:203) wat gesê het: 'Die kerk is alleen kerk as dit vir ander bestaan...' Armstrong (1979:38) deel hierdie oortuiging as hy sê: 'If there is one image in the Bible that expresses the mission of the church, it is that of a servant.'

Tog maak Dulles (2002:91-94) 'n saak daarvoor uit dat die hele saak van dienslewering gebrekkig is aan Bybelse begronding. Die Bybel prys wel dienslewering aan, maar dui nie die taak van die kerk as dienslewering (service) aan nie:
The modern notion of the 'servant Church' therefore seems to lack any direct foundation in the Bible. Yet it may be out of place to speak of an 'indirect foundation'.

(Dulles 2002:92-93)

Later vervolg hy:

The emphasis is apocalyptic rather than prophetic. The Church is seen as existing for the glory of God and of Christ, and for the salvation of its members in a life beyond the grave. It is not suggested that it is the Church's task to make the world a better place to live in.

(Dulles 2002:92-93)

Ten spyte van sy argumente, maak hy tog 'n toegewing deur die huidige aandrang op die kerk as dienskneg (servant Church), te sien as ' $n$ teken van spirituele vooruitgang. Maar onmiddellik waarsku hy weer: 'But the concept of service must be carefully nuanced so as to keep alive the distinctive mission and identity of the Church' (Dulles 2002:94).

Nie almal redeneer soos Dulles nie. In sy studie oor die werk van Newbigin formuleer Hunsberger (1998) Newbigin se siening soos volg:

... the best way to meet society in terms of the gospel - and avoid the possiblity of compromise - is for Christians [to] be the hermeneutic of the gospel - the interpretive lens through which people will see and read what the gospel has to do with them and the world in which they live.

(Hunsberger 1998:279)

Die gemeente moet geleer word om hierdie hermenieutiek vir die evangelie te wees en dit sou die eerste sendingtaak van die kerk wees, nie om die wêreld te verander nie maar om self te verander (Bosch 1979:246). Iets van hierdie verander word ook deur Guder (2000) in sy boek, The Continuing Conversion of the Church, bepleit. Moffitt (2006) se siening versterk hierdie argument as hy soos volg redeneer:

Christians talk about bringing unsaved people to church 'churching the unchurched'. Yet, the most effective way to reach people is by sending members out of the church and into the world. We need to 'unchurch the churched'! We need to cross the bridge that seperates the church from the community. People should not have to belong to the 'club' - the church - to find out that God loves them.

(Moffitt 2006:216)

Sider et al. (2002) meen dat daar wye konsensus onder Evangeliese leiers is dat die kerk beide Woord en daad moet kombineer deur evangelisasie en sosiale bediening te verrig. Volgens hulle is al hoe meer kerke besig om in 'n meer holistiese benadering op te gaan:

Holistic ministry is incarnational ministry .... It's God's people fleshing out the truth of the gospel... this means making personal commitment to service, not simply donating money from a distance.

(Sider et al. 2002:13)

In hulle boek, Churches that make a Difference, pleit Sider et al. (2002:27) vir betrokkenheid in die wêreld, maar dan vanuit' $n$ holistiese benadering. In hoofstuk 2: 'The church's calling to holistic mininstry', word die volgende gesê:

To spread the kingdom of God is more than simply winning people to Christ. It is also working for the healing of persons, 
families, and relationships. It is doing deeds of mercy and seeking justice.

(Sider et al. 2002:45)

DeClaissé-Walford (2008:6) ondersteun die gedagte en noem dat die Christendom fundamenteel oor gemeenskapsbetrokkenheid gaan. Hy gebruik die Bybelse beelde van sout en lig (Matt 5:13-16) en stel dit soos volg: '.... and I take this to mean that the church are less about numbers and more about effect.'

Nel (1994) noem dat God reeds en steeds in sy wêreld aktief is:

Hy is ook aktief besig in die gemeenskap waarbinne elke gemeente bestaan. Die gemeente is in die sin sy mense wat vir sy barmhartigheid sensitief geraak het. Soos niemand anders nie weet die gemeente dat God omgee en dat dit vir Hom saak maak wat van mense in hulle nood word.... Barmhartigheidsdiens is daarom die mees logiese diens wat die gemeente in sy missionêre gerigtheid op God se wêreld kan lewer. Dit is niks anders as missionêre diens of diakonaat nie. So neem die gemeente deel aan dit waarmee God besig is. Hulle raak betrokke by dit wat God reeds uit liefde doen vir mense in en rondom die gemeente - mense in hulle bestaan van sonde, hartseer, ongeregtigheid, onderdrukking, intimidasie, armoede, werkloosheid, eensaamheid, geweld en nog meer.

(Nel 1994:47)

Schutte (2003:248, 252-254) is ook oortuig dat die plaaslike gemeente nie anders kan as om plaaslik by haar gemeenskap betrokke te raak nie - ook wat haar barmhartigheidswerk betref:

Die dae toe evangelisasie net beteken het om siele vir die Koninkryk te wen, is met ander woorde verby ... evangelisasie beteken dus eerder ' $n$ holistiese benadering tot die mens wat buite die gemeente staan. Sy geestelike sowel as fisiese behoeftes moet raakgesien en aangespreek word.

(Schutte 2003:254)

Hy noem dat meeste lidmate nog nooit geleer is om die fisiese nood van ander raak te sien nie. Mense dink dat dit in die Kerk net om die geestelike nood van mense gaan. In elke gemeente sal 'n sensitiwiteit vir mense in nood gekweek moet word en die diakens sal die gemeente voortdurend vir barmhartigheidsdiens moet toerus. Daarby moet daar ook 'n klemverskuiwing van hoe die gemeente betrek kan word, plaasvind. Dit mag nie gesien word as 'n blote bereidwilligheid om ' $n$ bepaalde finansiële bydrae te lewer of om bepaalde middele by die kerk te kom aflaai nie. Elke lidmaat moet tot aktiewe deelname aangemoedig word.

Armstrong (1979:47) spesifiseer ook hierdie dienskneggestalte van die kerk deur te wys dat die kerk ' $n$ instrument van versoening moet wees waar konflik is; die kerk moet die instrument vir hervorming wees waar daar onreg is en waar daar lyding is moet die kerk ' $n$ gemeenskap wees wat medelye betoon terwyl die behoeftes van mense in nood aangespreek word. Ook ander skrywers sluit aan by hierdie saak van die kerk se 'dienskneggestalte'. Volgens Callahan (1983:1) is Spesifieke, Konkrete Missionêre doelwitte die eerste kenmerk van 'n suksesvolle gemeente. Daarby bedoel hy 'n gemeente wat fokus op spesifieke 'human hurt and hope' soos deur byvoorbeeld hulp aan alkoholiste en hulle families te verleen. Die gedagte is dat 'n gemeente met sodanige doelwitte werklike diens aan 'n gemeenskap sal lewer en in daardie diens ook ' $n$ missionale gerigtheid sal hê. Daar moet egter in so 'n benadering gewaak word om nie alles vir almal te wees nie. Dit is veral 'n vermaning aan die pastor wat soms neig om alles vir almal te wees en gevolglik uitbrand. En verder: "The church that does that, ends up helping no one with anything' (Sjogren 1993:17) definieer dit wat hy 'Servant Evangelism' noem, soos volg: 'Demonstrating the kindness of God by offering to do some act of humble service with no strings attached' (Sjogren 1993:18).

\section{In die praktyk}

Die werk van Moffitt (2006) werp goeie lig op die hele saak van diensevangelisasie en fisiese, sosiale bediening. Die kerk van die negentiende en twintigste eeu het ' $n$ tragiese verlies ervaar. Ten spyte van 'n groeiende getal kerke en Christene wêreldwyd, het die kerk haar vermoë om 'n impak op die wêreld te maak, verloor. Hy (Moffitt 2006:114)verwys ook na die kerk in die Apostolies era wat met 'n skrale 9.9\% die Romeinse wêreld van daardie tyd totaal beïnvloed het. Moffitt (2006:102) verwys ook deur woordspeling na die 'Greek' Commission (i.p.v. die Great Commission) omdat die vroeë kerk gekonfronteer was met die Gnostisisme, waarvolgens alles in die geestelike wêreld goed was, maar die fisiese wêreld boos was. Die kerk het 'n onbybelse onderskeid tussen fisiese en geestelike werklikhede ontwikkel - 'n onbybelse afstand tussen 'Woord' en 'dade'. Die internasionale kongres vir Wêreld Evangelisasie, wat in 1974 in Lausanne, Switserland gehou is, het ' $n$ keerpunt gebring omdat dit beide evangelisasie en sosiale betrokkenheid as sleutelkwessies uitgewys het (Moffitt 2006:115).

Hy identifiseer ses redes waarom die plaaslike gemeente die gemeenskap kan beïnvloed (Moffitt 2006:179-181):

1. Die plaaslike gemeente het 'n holistiese mandaat. Dit sluit alle aspekte van die indiwidu en gemeenskap se lewe in, naamlik hul fisiese, spirituele, sosiale en intellektuele behoeftes. God se breëre agenda maak dat die gemeente bedieninge in al die areas van mense se lewens bewerkstellig.

2. Die plaaslike gemeente bied voortdurende toerusting vir sy mense. Toerusting geskied deur middel van eredienste, Bybelstudiegroepe, kategese, kleingroepe ensovoorts, 'Equiping is far more than knowledge. It provides preparation and experience. It developes people's skills, attitudes, understanding, abilities, spiritual gifts, faith and faithfulness.'

3. Die plaaslike gemeente verteenwoordig 'n breë spektrum van die gemeenskap. As gemeenskap van gelowiges verteenwoordig die plaaslike gemeente alle sosioekonomiese klasse, etniese groepe, opvoedkundige vlakke en beroepe. Hierdie mense kan weer oral in hulle onderskeie leefwêrelde ' $n$ verskil maak. 
4. Die plaaslike gemeente is inheems. Die lidmate en leiers kom uit die gemeenskap wat die plaaslike gemeente bearbei.

5. Die plaaslike gemeente se bediening is volhoubaar. Die plaaslike gemeente onderhou haarself uit eie bronne en die uitreike is uit eie middele. Baie organisasies kom van buite af en moet gedurig geld en middele van buite genereer wat, sonder die volgehoue ondersteuning van buitepersoneel en hulpbronne, moeilik is om vol te hou.

6. Die plaaslike gemeente is ontwerp vir lewenslange betrokkenheid met haar lidmate. 'There are few other institutions where people come voluntarily, regularly, throughout their lives, to receive instruction about how to live.'

Daar is talle maniere en projekte waardeur die plaaslike gemeente in die gemeenskap betrokke kan raak. Verskillende skrywers haal letterlik dosyne voorbeelde van sodanige uitreike en projekte aan. Sjogren in sy Conspiracy of Kindness (1993), bied 'n lang lys van vindingryke maniere waarop 'n gemeente in die gemeenskap betrokke kan raak. Dit wissel van gloeilampe by huise vervang, gratis koeldrankies by sportbyeenkomste uitdeel, motors was tot selfs die skoonmaak van toilette by restaurante en besighede. Peters (2000) in sy boek, Tot Uw dienst: Een diakonale bijdrage aan gemeenteopbouw, noem onder andere die voorsiening van blyplek aan dakloses, diensbeurte by terminale pasiënte te doen, hulpdienste aan minder beweeglike mense te bied, maaltydprojekte, hulp met die inburgering van vreemdelinge en vlugtelinge, koinonia-geleenthede vir nuwe intrekkers ensovoorts. Sider et al. (2002) in Churches that make a difference inkorporeer deurentyd praktiese voorbeelde van hoe gemeentes 'n verskil kan maak. Gedurende 'n VSA-toer in 2004 saam met prof. Malan Nel het ons een oggend besoek afgelê in 'n stedelike gebied in die omgewing van Princeton. Ons gasheer vir die oggend was Philip Olsen, een van die mede-outeurs van die boek. Olsen het ons na 'n gemeente geneem en vertel hoedat die betrokke gemeente huisvesting vir armoedige gesinne bekom het en dit op 'n volhoubare manier aan hulle verhuur. Die gemeente was ook betrokke by verskeie behuisingsprojekte vir minder gegoede mense.

Wat Moffitt se boek (2006), If Jesus were Mayor, so waardevol maak, is dat dit oorloop van ware gebeure oor talle sendingvelde heen, veral ook in gebiede wat oorheersend uit ander godsdiensgroepe bestaan. Aan die einde van die boek gee hy 'n goeie uiteensetting van dit wat hy saadprojekte noem. Hy definieer dit as kortstondige, klein, eenvoudige bedieningsaktiwiteite wat deur die plaaslike gemeente verrig word deur die aanwending van eie hulpbronne ten einde God se liefde te demonstreer aan diegene buite die gemeente (Moffitt 2006:275). Die prinsipiële onderbou van die saadprojekte, asook die praktiese toepassing (Moffitt 2006:273-306) daarvan, is baie opwindend en insiggewend en behoort van groot waarde te wees vir enige plaaslike gemeente wat by die gemeenskap betrokke wil raak. Weens 'n gebrek aan ruimte word hier slegs na die voorbeeld van een saadprojek gekyk, naamlik dié van 'n gemeente in Tegucigalpa, Honduras, wat binne 'n paar jaar die volgende vermag het:
- 'n sokkerliga gereël

- 'n mediese liga gestig

- 'n kinderoppas-klas ingestel

- klere voorsien aan behoeftige kinders

- tandheelkundige dienste wat 'n tandarts aan huis van behoeftiges gaan lewer, verskaf

- tandheelkundige opleiding verskaf

- lakens aan gevangenes voorsien

- skooltoerusting vir gevangenes se kinders voorsien

- 'n voorkomende gesondheidseminaar gehou

- vitamine-aanvullings verskaf

- vullishouers in strate voorsien

- een keer 'n week gevas om kos aan behoeftiges te gee

- spoedhobbels in strate geverf

- families van alkoholiste besoek

- slaggate in strate opgevul

- 'n versoek vir 'n vullisverwyderingslorrie ingesit

- betontrappies by 'n steilte gebou.

Nel (1994:232) noem dat die gemeente die barmhartigste organisme op aarde behoort te wees. Hy (Nel 1994:233) stel ook die volgende vrae aan gemeentestrukture:

- Vergemaklik diestrukture die vloei van diebarmhartigheid van God en sy mense?

- Is dit moontlik om vinnig hulp en hoop aan diegene wat onverwags in nood kom, te verleen?

- Is die strukture vir hulpverlening 'mensvriendelik'?

- Word die menswaardigheid van mense in nood gehandhaaf of aangetas?

- Maak die strukture en vorme dit maklik vir mense wat hulp en hoop ontvang, om in te skakel by die gemeenskap van mense wat omgee en die lewe met mekaar deel?

Dit moet duidelik gestel word dat die diens van barmhartigheid, veral aan die gemeenskap, nie oor 'n goedkoop 'wen-van-siele' gaan nie; dit sou niks anders as 'n godsdienstige smousery, waar alles teen halfprys uitverkoop word, wees nie. Barmhartige dienslewering word altyd gemotiveer vanuit 'n nederige dankbaarheid vir die verlossing wat die gemeente in en deur Jesus Christus ontvang het. Die dank en eer kom Christus toe en die gemeente mag met geen bybedoeling te werk gaan soos byvoorbeeld om lidmate van ander gemeentes af te rokkel of om mense net ter wille van hulle bekering te bedien nie. Opregte dienslewering wat spruit uit ware liefde vir God en medemens werk aansteeklik; dit inspireer en maak 'n appèl op hulle wat gedien word. Dit maak ook 'n appèl op diegene wat op watter wyse ook al, as medewerkers by dienslewering betrokke raak - gelowig of nie gelowig nie. Wanneer mense tot geloof kom vanweë die toegewyde werk van die gemeente is dit alleen maar die werk van God en 'n neweproduk van 'n gehoorsame gemeente se werk. Die nuwe gelowiges of diegene wat hulle lidmaatskap wil heraktiveer, behoort aangemoedig te word om dit in 'n gemeente van hulle eie keuse te laat realiseer. Wanneer mense uiteindelik tog by die 'dienende gemeente' wil aansluit, geskied dit in 'n dankbare gesindheid teenoor die Heer van die Kerk wat alles moontlik gemaak het. 


\section{Empiriese studie}

Om te bepaal in hoe' $n$ mate gemeentes van die Nederduitsch Hervormde Kerk van Afrika (NHKA) en die Nederduitse Gereformeerde Kerk (NGK) betrokke is by onder andere gemeenskapsprojekte, is 'n totaal van 180 vraelyste per gewone pos uitgestuur. Van hierdie 180 gemeentes het 90 voorheen 'n gemeentebouproses deurloop onder leiding van Malan Nel. 'n Gemeente is dan deur die Departement Statistiek uit dieselfde ring toegewys as deel van die studie, vandaar die ander 90 gemeentes wat die totaal opmaak van 180. Geen onderskeid word in hierdie studie getref tussen gemeentes wat 'n gemeentebouproses deurloop het al dan nie. Hierdie studie wil slegs aantoon in watter mate die geselekteerde gemeentes by die diens van barmhartigheid in hul gemeenskappe betrokke is.

'n Totaal van 81 (45\%) van die vraelyste is terugontvang. Van die NHKA het 12 gemeentes op die vraelyste gereageer, terwyl 69 NGK gemeentes vraelyste teruggestuur het. Die meerderheid gemeentes wat gereageer het, is in Gauteng (43.2\%), gevolg deur Noordwes (23.5\%) en daarna Limpopo (18.5\%). Die oorblywende persentasies is deur die res van die provinsies opgemaak. Verder het $43.2 \%$ gemeentes uit die platteland gereageer; $51.9 \%$ was voorstedelike gemeentes en $4.9 \%$ gemeentes is in die middestad gesetel.

\section{Projekte in die gemeenskap}

Die betrokkenheid van gemeentes in hulle gemeenskap is van kardinale belang, soos beredeneer is. Deelnemende gemeentes kon aan die hand van die vraelys keuses maak uit 12 projekte waarby hulle betrokke is. Hulle kon ook addisionele aksies vermeld wat nie op die vraelys aangedui is nie. In twee van die daaropvolgende vrae kon gemeentes aandui hoe hulle, enersyds hul impak op die gemeenskap sou tipeer en andersyds die gemeenskap se siening ten opsigte van die gemeente se rol in die gemeenskap. Die tabel hieronder gee 'n aanduiding van die 12 projekte wat gestel is asook die respondente se reaksie op die vrae (Tabel 1). Let daarop dat Tabel 1 net reflekteer of dit 'n gemeenteprojek is, al dan nie. Die veronderstelling is dat, as kleingroepe byvoorbeeld by 'n aksie betrokke is, dit ook die gemeente is wat eienaarskap daarvoor neem.
Onderstaande tabel (Tabel 1) dui op 'n goeie antwoordsyfer van $87 \%$ en meer, ongeag of die gemeentes 'ja' of 'nee' ten opsigte van betrokkenheid aangedui het. In die tabel hieronder word die getalle en persentasies aangedui van die onderskeie onderafdelings by elke projek. Neem byvoorbeeld die sopkombuisprojek. Daar het 53 uit die 71 gemeentes aangedui dat hulle by 'n sopkombuis betrokke is wat neerkom op 'n persentasie van $74.6 \%$. By die aantal kleingroepe betrokke, het net 50 respondente die vraag geantwoord, waarvan 25 gemeentes se kleingroepe betrokke is en 25 gemeentes aangedui het dat geen kleingroep betrokke is nie, vandaar die waarde van $50 \%$. By finansiële betrokkenheid het 66 respondente geantwoord waarvan 48 gemeentes $(73.1 \%)$ finansieel bydra en 18 geen bydraes gelewer het nie. Wat die langtermyn- en korttermynkolomme betref, het 57 gemeentes (49 langtermyn betrokke en 8 korttermyn betrokke) geantwoord met die totale persentasie wat optel na $100 \%$ toe. Dieselfde werkswyse geld vir die res van die tabel.

Die volgende tabel (Tabel 2) gee ' $n$ aanduiding van die gemeentes se betrokkenheid wat wel aangedui het dat hul by die onderstaande projekte betrokke is.

Ten einde sin te maak uit al die inligting in hierdie tabelle, is dit makliker om dit in groepe te klassifiseer en dan ' $n$ oorsigtelike beeld van die gemeentes se betrokkenheid te vorm. Die aksies wat in sinvolle eenhede saamhoort, is voedsel en kleding (sopkombuis, nie-bederfbare voedsel, klere en komberse); behuising in die algemeen (deurgangbehuising, behuising vir hulpbehoewendes, ouetehuise en kinderhuise); algemene sorg (straatkinders; vigs- en ander terminale pasiënte, plakkerskampe); die beskikbaarstelling van gemeentefasiliteite (gratis vir instansies in gemeenskap, vir opvoedkundige doeleindes van die gemeenskap).

\section{Projekte ten opsigte van voedsel en kleding}

Respondente het goed op hierdie afdelings gereageer en alle aanduidings is daar dat hierdie basiese vorm van hulpverlening in die algemeen hoog op die agenda by gemeentes is. Die persentasie respondente (74.6\% en hoër) dui op uitstekende betrokkenheid by die direkte en materiële nood van die gemeenskap in die onmiddellike omgewing.

TABEL 1: Aantal gemeentes wat geantwoord het.

\begin{tabular}{|c|c|c|c|c|c|c|}
\hline \multirow[t]{3}{*}{ Projekte } & \multicolumn{6}{|c|}{ Gevalle } \\
\hline & \multicolumn{2}{|c|}{ Geldig } & \multicolumn{2}{|c|}{ Ontbrekend } & \multicolumn{2}{|c|}{ Totaal } \\
\hline & Aantal & $\%$ & Aantal & $\%$ & Aantal & $\%$ \\
\hline Sopkombuis & 71 & 87.7 & 10 & 12.3 & 81 & 100 \\
\hline Nie-bederfbare kos & 74 & 91.4 & 7 & 8.6 & 81 & 100 \\
\hline Klere en komberse & 78 & 96.3 & 3 & 3.7 & 81 & 100 \\
\hline Deurgangbehuising & 75 & 92.6 & 6 & 7.4 & 81 & 100 \\
\hline Straatkinders & 73 & 90.1 & 8 & 9.9 & 81 & 100 \\
\hline Behuising: hulpbehoewendes & 71 & 87.7 & 10 & 12.3 & 81 & 100 \\
\hline Terminale sorg & 71 & 87.7 & 10 & 12.3 & 81 & 100 \\
\hline Ouetehuise & 73 & 90.1 & 8 & 9.9 & 81 & 100 \\
\hline Kinderhuise & 75 & 92.6 & 6 & 7.4 & 81 & 100 \\
\hline Fasiliteite: instansies & 75 & 92.6 & 6 & 7.4 & 81 & 100 \\
\hline Fasiliteite: opvoed & 77 & 95.1 & 4 & 4.9 & 81 & 100 \\
\hline Plakkerskampe & 73 & 90.1 & 8 & 9.9 & 81 & 100 \\
\hline
\end{tabular}

Bron: Ungerer, A., 2010, 'Die verband tussen gemeentebouprosesse en missionale gemeenteontwikkeling: 'n Prakties Teologiese Studie', PhD proefskrif, Departement Praktiese Teologie, Universiteit van Pretoria 
TABEL 2: Projekte waarby gemeentes betrokke is.

\begin{tabular}{|c|c|c|c|c|c|c|c|c|c|c|}
\hline \multirow[t]{2}{*}{ Projekte } & \multicolumn{2}{|c|}{ Gemeentes } & \multicolumn{2}{|c|}{ Kleingroepe betrokke } & \multicolumn{2}{|c|}{$\begin{array}{l}\text { Gemeentes wat } \\
\text { finansieel bydra }\end{array}$} & \multicolumn{2}{|c|}{ Langtermyn } & \multicolumn{2}{|c|}{ Korttermyn } \\
\hline & Aantal & $\%$ & Aantal & $\%$ & Aantal & $\%$ & Aantal & $\%$ & Aantal & $\%$ \\
\hline $\begin{array}{l}\text { 1. Bemanning van sopkombuis of } \\
\text { fisiese betrokkenheid by enige ander } \\
\text { voedingskema. }\end{array}$ & 53 & 74.6 & 25 & 50.0 & 48 & 73.1 & 49 & 86.0 & 8 & 14.0 \\
\hline $\begin{array}{l}\text { 2. Voorsiening van nie-bederfbare } \\
\text { voedsel aan instansies. }\end{array}$ & 65 & 87.8 & 32 & 67.9 & 49 & 80.8 & 47 & 79.7 & 12 & 20.3 \\
\hline $\begin{array}{l}\text { 3. Voorsiening van klere en komberse } \\
\text { aan instansies. }\end{array}$ & 74 & 94.9 & 32 & 71.5 & 44 & 69.5 & 45 & 71.4 & 18 & 28.6 \\
\hline $\begin{array}{l}\text { 4.Verskaffing van deurgangbehuising } \\
\text { vir haweloses }\end{array}$ & 14 & 18.7 & 3 & 9.4 & 14 & 22.3 & 10 & 58.8 & 7 & 41.3 \\
\hline $\begin{array}{l}\text { 5. Betrokkenheid by die rehabilitering } \\
\text { of versorging van straatkinders. }\end{array}$ & 17 & 23.3 & 5 & 9.0 & 17 & 29.0 & 13 & 61.9 & 8 & 38.1 \\
\hline $\begin{array}{l}\text { 6. Voorsiening van behuising aan } \\
\text { hulpbehoewendes. }\end{array}$ & 24 & 33.8 & 8 & 16.2 & 23 & 38.6 & 19 & 76.0 & 6 & 24.0 \\
\hline $\begin{array}{l}\text { 7. Hulp met die versorging van vigs- of } \\
\text { ander terminale pasiënte. }\end{array}$ & 26 & 36.6 & 14 & 26.5 & 23 & 39.6 & 26 & 86.7 & 4 & 13.3 \\
\hline 9. Betrokkenheid by kinderhuise & 57 & 76.0 & 29 & 58.2 & 48 & 78.6 & 47 & 85.5 & 8 & 14.5 \\
\hline $\begin{array}{l}\text { 10.Verskaffing van gemeente se } \\
\text { fasiliteite (gratis) aan instansies } \\
\text { vir enige liefdadigheids- of } \\
\text { opheffingswerk. }\end{array}$ & 52 & 69.3 & 11 & 27.8 & gratis & gratis & 37 & 77.1 & 11 & 22.9 \\
\hline $\begin{array}{l}\text { 11.Gemeente gebruik eie fasiliteite vir } \\
\text { enige opvoedkundige doeleindes } \\
\text { wat op die gemeenskap gerig is. }\end{array}$ & 47 & 61.0 & 13 & 27.9 & gratis & gratis & 30 & 83.3 & 6 & 16.7 \\
\hline 12.Betrokke by plakkerskampe & 25 & 34.2 & 11 & 22.8 & 17 & 35.4 & 16 & 61.5 & 10 & 38.5 \\
\hline
\end{tabular}

Die hoë persentasie van $87.8 \%$ en $94.9 \%$ van respondente wat betrokke is by die uitdeel van nie-bederfbare voedsel asook klere en komberse, veronderstel goeie strukture wat die verkryging en verspreiding van hierdie middele vergemaklik. Dit is verblydend dat 'n redelike persentasie kleingroepe by hierdie projekte betrokke is. Die persentasie gemeentes wat finansiële bydraes lewer, is hoog en 'n hoë persentasie gemeentes is op ' $n$ langtermynbasis hy hierdie projekte betrokke.

\section{Projekte ten opsigte van behuising in die algemeen}

Die persentasie gemeentes wat by deurgangbehuising en die verskaffing van behuising aan hulpbehoewendes betrokke is, is heelwat kleiner as in die geval van voedsel en kleding. In die geval van deurgangbehuising vir haweloses is dit so laag as $18.7 \%$. Meer gemeentes $(33.8 \%)$ is betrokke by die voorsiening van behuising aan hulpbehoewendes. Kleingroepe toon uiteraard 'n laer persentasie van betrokkenheid aangesien dit moeiliker is vir 'n klein groepie mense om op 'n groter skaal betrokke te wees. Selfs die aantal gemeentes wat in hierdie verband finansiële bydraes lewer is minder. Dit het waarskynlik te make met die feit dat groter koste en administratiewe monitering by behuising betrokke is. Gemeentes se langtermynbetrokkenheid by deurgangbehuising en behuising aan hulpbehoewendes is redelik (58.8\% en $76 \%)$.

Wat ouetehuise en kinderhuise betref, is die betrokkenheid van die respondente by hierdie instansies weer groter $(87.7 \%$ en $76 \%$ ). Die getal kleingroepe is ook groter en die aantal gemeentes wat finansiële bydraes lewer is goed. Gemeentes kry dit ook reg om in groter persentasies langtermyn betrokkenheid by hierdie instansies te toon.
Ouetehuise en kinderhuise is normaalweg goed gevestig in gemeenskappe en is meestal staatsondersteunde instellings waarby gemeentes hulp op allerlei maniere kan bied. Betrokkenheid by die daarstelling van deurgangbehuising en behuising aan hulpbehoewendes is veel moeiliker, omdat dit groter organisasie in terme van finansies, personeel en hulpbronne verg.

\section{Projekte ten opsigte van algemene sorg}

Betreklik min respondente $(23.3 \%)$ het aangedui dat hulle by straatkinders betrokke is. Wat kleingroepe betref, was dit, naas deurgangbehuising $(9.4 \%)$, op die laagste vlak van betrokkenheid met 'n skrale $9 \%$. Die rede sou waarskynlik daarin lê dat dit veel moeiliker is om 'n greep op hierdie mense se bewegings te kry en om hulle doen en late te bestuur. Behalwe behuising en voorsiening van voedsel en kleding, is 'n rehabilitasieprogram meestal ook nodig - 'n omvattende hulpverleningsprojek waarvoor min gemeentes klaarblyklik hulle weg oopsien.

Wat sorg aan pasiënte met vigs en ander terminale siektes betref, was daar ietwat meer gemeentes (36.6\%) betrokke. Daar was nie in die vraelys 'n spesifieke verwysing na die aantal vigspasiënte nie hoewel daar aanvaar kan word dat hulle tog 'n sekere persentasie uitgemaak het. Dit is verblydend dat daar aanduidings van 'n langtermyn verbintenis met hierdie siekes is.

Daar is $34.2 \%$ gemeentes $(22.8 \%$ kleingroepe) by plakkerskampe betrokke terwyl dit bemoedigend is dat $61.5 \%$ van hierdie betrokke gemeentes wel op 'n langtermynbasis betrokke is.

Gemeet aan die persentasie gemeentes wat betrokke is by projekte ten opsigte van algemene sorg, is daar 'n 
redelike vermoede dat hierdie projekte die 'stiefkinders' van hulpverleningsbedieninge is. Hoewel die vraelyste nie pertinent gevra het na gesindheid en vooroordeel nie, kan daar tog gevra word in watter mate dit 'n rol speel in gemeentes se betrokkenheid by hierdie mense in ons samelewing.

\section{Projekte ten opsigte van beskikbaarstelling van gemeentefasiliteite}

Die meeste gemeentes beskik oor uiters doelmatige fasiliteite en strukture wat meestal net op Sondae gebruik word. Daar is dikwels in die gemeenskap organisasies wat liefdadigheids- en opheffingswerk doen wat ' $n$ behoefte het aan die doelmatige fasiliteite op 'n langtermynbasis. Die groter getal gemeentes $(69.3 \%$ en $61 \%)$ wat hulle fasiliteite vir verskillende instansies beskikbaar stel, is bemoedigend. Behalwe dat dit die sigbaarheid van die kerkkompleks verhoog, dui dit op 'n gesindheid van 'n gemeente wat ook die gemeenskap met hulle fasiliteite dien.

\section{Ander projekte in die gemeenskap}

Benewens die 12 voorbeelde van dienslewering wat genoem is en waarop gemeentes kon reageer, was daar ook geleentheid om ander projekte aan te dui. Hierdie projekte word bloot vir interessantheid in die volgende lys weergegee. As ' $n$ mens deur die lysie kyk, is dit verblywend om die kreatiwiteit van gemeentes te sien, asook die wye spektrum van dienslewering waarby hulle betrokke geraak het:

- leierskap en enterpreneursopleiding vir agtergeblewenes

- paroolinskakeling by gemeenskap

- roei-akademie (leer swart kinders kanosport en lewensvaardighede

- bou van basis vir FCE (Foundation for cross-cultural education) in Zambië

- opleiding van swart lekepredikers in samewerking met prof. Malan Nel

- naaldwerkklasse vir vroue

- traumaberaad vir misdaadslagoffers

- hulpverlening by mediese kliniek (skoonmaak, besoek, middele)

- Meer-as-'n-nommer-projek (spuitverf nommers gratis op sypaadjies en deel 'n lys van noodnommers uit)

- Geel-handskoenprojek (lidmate aanvaar verantwoordelikheid vir opruim van omgewing)

- aksie 'optel' (betaal werkloses om strate skoon te maak)

- betrokke by Winterveld ashoopgemeenskap

- betrokke by versorgingsprojek vir geregistreerde weeskinders

- opleiding van kerkleiers deur middel van Nehemia Bybelinstituut

- Adonai-sentrum vir multigestremdes

- enterpreneursbediening (opleiding van sakemanne)

- werkverskaffingsprojek (laat 15 werkloses eetgerei poleer)

- 'Xtreme makeover' (8 huise reeds opgeknap om inwoners selfrespek te laat herwin)

- ondersteuning en finansiële hulp aan mishandelde vroue

- kamp vir plaaswerkers

- skryfbehoeftes en kersgeskenke aan behoeftige kinders.
Die 12 projekte, asook die verskillende projekte wat by bostaande punte aangedui word en tot dusver bespreek is, bied ' $n$ beknopte weergawe van ure, dae, maande en jare se geswoeg en sweet in God se koninkryk. Togkom'n mens onder die indruk van die omvang van barmhartigheidsprojekte in groot dele van die land.

\section{Die gemeente se impak op die plaaslike gemeenskap}

Hierdie vraag is gestel om by die respondente vas te stel wat sy of haar algemene indruk van sy of haar gemeente se rol in die gemeenskap is. Soos ' $n$ respondent tereg opmerk: 'Die antwoorde kan nie as feitelik korrek aanvaar word nie, aangesien dit nie gestaaf kan word deur 'n steekproef of ander opname nie.' Aan die ander kant is dit is tog goed om gemeentes se 'selfbeeld' aan die hand van hierdie vraag te toets.

Die vraag het soos volg gelui en daar is versoek dat gemeentes net een keuse moes maak: 'Op watter wyse sou $\mathrm{u} \mathrm{u}$ gemeente se impak op die plaaslike gemeenskap tipeer? Merk slegs een van die volgende moontlikhede.' Tabel 3 dui die vrae aan, asook die aantal gemeentes wat die verskillende moontlikhede gemerk het en die persentasiepunt.

Die grootste oorwig gemeentes het punt ' $d$ ' gemerk (Tabel 3).

\section{Die gemeenskap se siening ten opsigte van die gemeente se rol}

Hierdie aspek het ook met ' $n$ 'selfbeeld' vraag te doen en vra na die respondent se opinie oor wat die respondent meen die gemeenskap se siening oor die gemeente is. Die vraag is soos volg geformuleer: 'Wat is volgens $u$ die siening van die gemeenskap ten opsigte van $u$ gemeente se rol in die gemeenskap?' Respondente kon slegs een van die volgende merk:

- Baie in die gemeenskap herken die belangrike rol wat die gemeente in die lewe van die gemeenskap vervul.

- Die gemeenskap kyk na die gemeente vir ondersteuning om die gemeenskap se behoeftes aan te spreek.

- Die gemeenskap kyk na die gemeente vir leierskap om die gemeenskap se behoeftes aan te spreek.

- Die gemeenskap neem kennis van die gemeente.

- Die gemeenskap neem nie regtig kennis van ons gemeente nie.

TABEL 3: Die gemeentes se eie siening oor hul impak op die plaaslike gemeenskap.

\begin{tabular}{lcc}
\hline Impak op die plaaslike gemeenskap & Totaal & $\mathbf{\%}$ \\
\hline $\begin{array}{l}\text { 1. Die gemeente is grootliks onbetrokke by die gemeenskap. } \\
\begin{array}{l}\text { 2. Die gemeente het eerste pogings begin aanwend om die } \\
\text { gemeenskap tot diens te wees. }\end{array}\end{array}$ & 6 & 10.1 \\
$\begin{array}{l}\text { 3. Die gemeente het reeds ten minste een area in die } \\
\text { gemeenskap geïdentifiseer waar diens verrig kan word. }\end{array}$ & 14 & 17.7 \\
$\begin{array}{l}\text { 4. Die gemeente is betrokke in voortgaande en volhoubare aksies } \\
\text { wat God se liefde aan die mense in die gemeenskap demonstreer. }\end{array}$ & 51 & 64.6 \\
\hline Groot totaal & $\mathbf{7 9}$ & $\mathbf{1 0 0}$ \\
\hline
\end{tabular}

Bron: Ungerer, A., 2010, 'Die verband tussen gemeentebouprosesse en missionale Bron: Ungerer, A., 2010, 'Die verband tussen gemeentebouprosesse en missionale
gemeenteontwikkeling: 'n Prakties Teologiese Studie', PhD proefskrif, Departement Praktiese Teologie, Universiteit van Pretoria 
TABEL 4: Siening van die gemeenskap ten opsigte van die gemeente se rol.

\begin{tabular}{lcc}
\hline Siening & Getal & $\mathbf{\%}$ \\
\hline Positief & 54 & 67.5 \\
Negatief & 26 & 32.5 \\
\hline Totaal & $\mathbf{8 0}$ & $\mathbf{1 0 0}$ \\
\hline
\end{tabular}

Bron: Ungerer A, 2010, 'Die verband tussen gemeentebouprosesse en missionale gemeenteontwikkeling: 'n Prakties Teologiese Studie', PhD proefskrif, Departement Prakties Teologie, Universiteit van Pretoria

Dit is opmerklik dat die grootste persentasie (67.5\%) gemeentes reken dat die gemeenskap 'n positiewe siening van die gemeente se rol het. Daar was 20 respondente wat gemeen het die gemeenskap neem net kennis van die gemeente en 6 het gevoel dat die gemeenskap nie regtig kennis neem nie.

\section{Samevattende opmerkings oor die empiriese studie}

Hierdie empiriese studie is nie omvattend genoeg om tendense op nasionale vlak aan te dui nie. Soos reeds aangedui, was die grootste persentasie deelnemende gemeentes gesetel in Gauteng (43.2\%), gevolg deur Noordwes (23.5\%) en daarna die Limpopo (18.5\%) Provinsie. Die oorblywende persentasies is deur die res van die provinsies opgemaak. Verder was $51.9 \%$ voorstedelike gemeentes, $43.2 \%$ op die platteland en $4.9 \%$ in die middestad geleë. Dit laat ' $n$ mens hoogstens met ' $\mathrm{n}$ indruk oor in watter mate die 81 deelnemende gemeentes van die onderskeie provinsies in hulle gemeenskappe betrokke is. Hoewel geen tendense afgelei kan word nie, bied hierdie gemeentes se werksaamhede tog 'n goeie idee van hoe dit in hulle streke gaan. Die leser het die voordeel om die resultate van hierdie studie te vergelyk met sy of haar eie gemeente se graad van betrokkenheid. Die volgende punte word as samevattende opmerkings oor die empiriese studie uitgewys:

- Daar was 'n goeie antwoordsyfer ten opsigte van die 12 projekte wat as voorbeelde voorgehou is. Die persentasie tussen $87.7 \%$ en $96.3 \%$ dui op 'n gesonde besef van gemeentes se verpligtinge teenoor hulle gemeenskappe ten opsigte van barmhartigheidsdiens.

- Die indruk word gewek dat dit vir meeste gemeentes steeds makliker is om middele soos nie-bederfbare voedsel, klere en komberse te versamel en dan te versprei. Die hoë persentasie gemeentes ('n gemiddelde van 85.8\%) by die projekte vir voedsel en kleding versterk hierdie indruk. Hoewel 'n redelike persentasie kleingroepe ('n gemiddelde van 63\%) by hierdie projekte betrokke is, kan daar nie met sekerheid gesê word hoeveel mense byvoorbeeld fisies by 'n sopkombuis betrokke is nie.

- Projekte ten opsigte van deurgangbehuising en behuising van hulpbehoewendes verg baie van gemeentes in terme van finansies, administrasies en monitering. Die gemiddelde persentasie van betrokke gemeentes by hierdie twee projekte is redelik laag $(26.3 \%)$ teenoor ' $n$ hoër gemiddeld van die meer institusionele en gevestigde behuising soos ouetehuise en kinderhuise (81.9\%).

- By projekte ten opsigte van algemene sorg is die persentasie betrokke gemeentes (31.4\%) steeds aan die lae kant. Behalwe vir die verskaffing van behuising, voedsel en kleding, word daar baie geverg in terme van voltydse sorg, rehabilitasie en vaardigheidsopleiding, wat alles aksies is wat geweldige uitdagings aan gemeentes stel.

- Van die maklikste maniere vir gemeentes om by hul gemeenskap betrokke te wees, is om hul gemeentesentrums en fasiliteite gratis beskikbaar te stel aan bestaande organisasies wat by voortdurende hulpverlening en opleidingsprogramme betrokke is. Afgesien van die beskikbaarstelling van die fasiliteite bied dit ook aan lidmate die geleentheid om by hierdie projekte betrokke te raak. ' $n$ Verdere voordeel is dat dit die sigbaarheid van die gemeente in die gemeenskap verhoog.

- Dit blyk dat die deelnemende gemeentes oor die algemeen 'n gunstige siening het van die rol wat hulle in die gemeenskap vervul, sowel as oor die gemeenskap se siening van die gemeente.

\section{Samevattende gedagtes}

Die deelnemende gemeentes wat deel uitgemaak het van die empiriese studie bied ' $n$ redelike prentjie van hoe diens aan die gemeenskap daarna uitsien. Die volgende word as samevattende gedagtes gestel:

- Dit blyk tog uit die antwoorde van die deelnemende gemeentes dat daar ' $n$ redelike bewustheid bestaan oor die belangrikheid van hul betrokkenheid in die gemeenskap. Die 12 projekte wat as voorbeelde genoem is, is hoofsaaklik aksies wat gemeenskapsgedrewe is en die hoë persentasie gemeentes wat op al hierdie vrae gereageer het, bevestig hierdie aanname.

- Oor die algemeen blyk dit dat gemeentes meer geneë is om by makliker projekte betrokke te raak, soos die insameling en verspreiding van voedsel, kleding en komberse. Die finansiële bydraes van gemeentes in hierdie verband bevestig dit. Dit blyk verder uit hul betrokkenheid en bydraes by die meer gevestigde instellings soos kinderhuise en ouetehuise, asook die beskikbaarstelling van gemeentefasiliteite aan organisasies wat reeds besig is met hulpverlening en opleidingsprogramme.

- Dit blyk dat min gemeentes betrokke is by projekte wat groter koste, volgehoue betrokkenheid, deeglike administrasie en voortdurende rehabilitasieprogramme insluit, soos byvoorbeeld die versorging van straatkinders en deurgangbehuising. Daarby kan 'n redelike onbetrokkenheid by plakkerskampe moontlik verklaar word deurdat hulle vêr van die gemeentes geleë is of dalk selfs dui op rassevooroordele. Die feit is dat aansienlik minder gemeentes by hierdie soort projekte betrokke is en dat die werklike redes hiervoor 'n eiesoortige studie verg.

- Die lang lys van innoverende projekte wat gemeentes aangedui het ten opsigte van hulle betrokkenheid in die gemeenskap is interessant en bemoedigend.

Hierdie studie het begin met die vraag of die betekenis van God is liefde op baie kanselklede nie maar net woorde op lappe is wat in kerkgeboue agtergelaat word terwyl'n wêreld daarbuite honger na God se liefde nie. Die veronderstelling is 
dat die gemeente buite die vier mure van die kerkgebou by uitstek draers en uitdelers van God se liefde behoort te wees. Met die teologiese begronding is aangedui hoekom dit nodig is dat God se liefde deur middel van barmhartigheidsdiens, behalwe aan lidmate ook aan mense (nie-lidmate) buite die gemeente, tasbare gestalte moet kry. Met die empiriese studie is gekyk na die deelnemende gemeentes se betrokkenheid by 12 projekte wat as voorbeeld gedien het asook ander projekte wat hulle kon aandui. Die oorwoë indruk is dat hierdie gemeentes ' $n$ redelike bewustheid het van die belangrikheid om in die gemeenskap betrokke te raak en in 'n redelike mate tot aksie oorgaan, veral by die 'makliker' projekte.

Tog is dit dalk nie billik om net aan die hand van syfers en statistiek te oordeel nie. Hoe verreken 'n mens die nood van die gemeenskap, die gesindheid waarmee gelowiges onbaatsugtige diens lewer, ure wat spandeer word aan die opstel van diensroosters, die insameling van middele, die moegheid van mense wat ure op die voete is om nood te verlig? Hoe heg jy 'n waarde aan sweet en trane, konflikte wat mag opduik en hanteer moet word, slapelose nagte van kommer omdat die omvang van nood 'n mens wil oorweldig, skuldgevoelens omdat gemeentes nog nie naastenby genoeg doen nie? 'n Mens voel om in die taal van die Bybel vir elke gemeente wie se betrokkenheid by die gemeenskap in hierdie studie reflekteer (en ook menige ander gemeentes) te sê: 'Mooi so! Jy is 'n goeie en getroue slaaf. Oor min was jy getrou, oor baie sal Ek jou aanstel' (Matt 25:21). Aan die ander kant behoort daar by die gemeente die blywende versugting te wees om steeds beter te doen, en meer lidmate te mobiliseer om by meer projekte in die gemeenskap betrokke te wees.

\section{Erkenning Mededingende belange}

Die outeur verklaar dat hy geen finansiële of persoonlike verbintenis het met enige party wat hom nadelig kon beïnvloed in die skryf van hierdie artikel.

\section{Literatuurverwysings}

Armstrong, R.S., 1997, Service Evangelism, Westminster Press, Philadelphia, PA. Bonhoeffer, D., 1967, Letters and Papers from Prison, Macmillan, New York, NY Bosch, D.J., 1991, Transforming Mission: Paradigm Shifts in Theology of Mission, Orbis Books, New York, NY

Callahan, K.L., 1983, Twelve Keys to an Effective Church, Harper Collins Publishers, San Francisco, CA

DeClaissé-Walford, S., 2008, Mission as Holistic Ministry: Developing a Congregational Ethos of Community Engagement, Smyth \& Helwys Publishing, Inc., Macon, GA. Dulles, A., 2002 [1974], Models of the Church: Expanded edition, Doubleday, NY.

Guder, D.L., 2000, The Continuing Conversion of the Church, Eerdmans Publishing Company, Grand Rapids, NY.

Hancke, F.J., 2005, 'Factors influencing comprehensive personal witness and enlarging missional involvement in the local church', PhD thesis, Department of Theology, University of the Free State.

Heitink, G., 2007, Een kerk met karakter: Tijd voor heroriëntasie, Kok, Kampen.

Hunsberger, G.R., 1998, Bearing the witness of the Spirit: Lesslie Newbigin's Theology of Cultural Plurality, Eerdmans, Grand Rapids, MI.

Moffitt, B., 2006, If Jesus were Mayor: How your local church can transform your community, Monarch Books, Grand Rapids, MI.

Nel, M., 1994, Gemeentebou, Orion Uitgewers, Halfway House.

Peters, A., 2000, Tot Uw dienst: Een diakonale bijdrage aan gemeenteopbouw Uitgeverij Boekencentrum, Zoetemeer.

Schutte, P.J.W., 2003, 'Missionêre diakonaat: 'n Uitdaging vir die kerk', HTS Teologiese Studies/Theological Studies 59(1), 247-264.

Sider, R.J., Olson, P.N., Unruh, H.R., 2002, Churches that make a difference: Reaching your Community with Good News and Good Works, Baker Books, Grand Rapids, $\mathrm{MI}$.

Sjogren, S., 1993, Conspiracy of Kindness: A Refreshing New Approach to Sharing the Love of Jesus with Others, Vine Books, Ann Arbor, MI.

Ungerer, A., 2010, 'Die verband tussen gemeentebouprosesse en missionale gemeenteontwikkeling: 'n Prakties Teologiese Studie', PhD proefskrif, Departement Praktiese Teologie, Universiteit van Pretoria.

Van Rensburg, E., 2009, God seën Afrika: Stories, gebede en wyshede, Lux Verbi. BM (Edms) Bpk., Wellington. 